\title{
Menggagas Konsep Dekriminalisasi Pencemaran Nama Baik Sebagai Pelanggaran Hukum Perdata Murni
}

\author{
Sheila Maulida Fitri \\ Kementerian Pertahanan RI \\ Jln. Medan Merdeka Barat No. 13-14 Jakarta Pusat, Indonesia \\ sheilamaulidaf@gmail.com
}

\begin{abstract}
Law always comes late as opposed to the social deveopment, existing laws are sometimes no longer able to provide solutions to social problems that occur. It is the same with defamation offenses that are blooming in Indonesia. Settlement of cases through criminal law is considered ineffective to resolve the existing problems. This study aims to identify the problem of law enforcement on defamation offenses in Indonesia and providing the right arguments on the urgency of decriminalizing defamation offenses and altering them onto violations of civil law instead. The research method used is a normative juridical with statutory, analytical approach and comparative approaches. The results of the study conclude that law enforcement on defamation offenses using criminal law efforts is considered ineffective because of problems in the material and formal legal aspects of the related article. The imposition of sanctions in the form of corporal punishment actually creates a new social problem and often does not fulfill the sense of justice for both the perpetrator and the victim, especially if the perpetrator's actions cause material losses. Hence the settlement through civil law is considered very appropriate considering that the majority of defamation occurs between individuals. This is also in order to re-establish the existence of criminal law as the ultimum remedium.
\end{abstract}

Key Word: Decriminalization; defamation; tort

\begin{abstract}
Abstrak
Hukum dinilai selalu tertinggal dari kehidupan sosial di masyarakat, hukum yang sudah ada terkadang tidak lagi mampu memberikan solusi atas permasalahan sosial yang terjadi. Sama halnya dengan delik pencemaran nama baik yang marak terjadi di Indonesia. Penyelesaian kasus melalui hukum pidana dinilai tidak efektif untuk menyelesaikan permasalahan yang ada. Penelitian ini bertujuan untuk mengetahui bagaimana masalah penegakan hukum atas delik pencemaran nama baik di Indonesia dan argumentasi yang tepat mengenai urgensi dekriminalisasi delik pencemaran nama baik dan menjadikannya murni sebagai pelanggaran hukum perdata. Metode penelitian yang digunakan adalah yuridis normatif, dengan pendekatan perundang-undangan dan komparatif. Hasil dari penelitian menyimpulkan bahwa penegakan hukum atas delik pencemaran nama baik menggunakan upaya hukum pidana dinilai tidak efektif karena adanya permasalahan pada aspek hukum materiil dan formil terhadap pasal terkait. Penjatuhan sanksi berupa pidana badan justru menimbulkan satu masalah sosial baru dan seringkali tidak memenuhi rasa keadilan baik bagi pelaku maupun korban terlebih jika perbuatan pelaku sampai menimbulkan kerugian materiil. Sehingga penyelesaian melalui hukum perdata dinilai sangat tepat mengingat pencemaran nama baik mayoritas terjadi antar sesama individu. Hal ini juga demi menegakkan kembali eksistensi hukum pidana sebagai ultimum remedium.
\end{abstract}

Kata-kata Kunci: Dekriminalisasi; pencemaran nama baik; perbuatan melawan hukum 


\section{Pendahuluan}

Perkembangan zaman akibat kemajuan teknologi yang begitu pesat mempengaruhi banyak hal tanpa terkecuali pada jenis dan modus suatu kejahatan. Hal ini mengakibatkan posisi hukum seringkali belum dapat menjangkau permasalahan-permasalahan yang ada ("Het Recht Inackhter de Feiten $\left.A a n^{\prime \prime}\right)^{1}$ atau bahkan instrumen hukum yang ada dinilai sudah tidak lagi relevan dan justru menimbulkan masalah hukum maupun sosial baru. Salah satu tindak pidana yang akhir-akhir ini marak terjadi yaitu delik pencemaran nama baik. Dalam sistem hukum pidana Indonesia dikenal dua jenis delik pencemaran nama baik yaitu yang dilakukan secara konvensional maupun melalui media elektronik.

Delik pencemaran nama baik secara konvensional diatur dalam Pasal 310 Kitab Undang-Undang Hukum Pidana (KUHP) sedangkan pencemaran nama baik secara elektronik diatur dalam Pasal 27 ayat (3) Undang-Undang No. 11 Tahun 2008 tentang Informasi dan Transaksi Elektronik jo Undang-Undang No. 19 Tahun 2016 tentang Perubahan atas UU No. 11 Tahun 2008 tentang Informasi dan Transaksi Elektronik (UU ITE). Keduanya memiliki konsep norma hukum yang sama, yang membedakan hanyalah media dimana perbuatan mencemarkan nama baik itu dilakukan dan cara melakukannya.

Hukum positif Indonesia memang telah memiliki instrumen hukum yang mengakomodasi kebutuhan penegakan hukum atas delik pencemaran nama baik. Namun bukan berarti tidak ada permasalahan yang timbul baik dalam aspek penegakan hukumnya. Kemajuan teknologi dan kemudahan akses media sosial khususnya, turut serta memberikan kontribusi terjadinya pencemaran nama baik. Hal ini bukan tanpa dasar, mengingat semakin marak terjadi dimana masyarakat saling melaporkan dengan tuduhan pencemaran nama baik khususnya yang dilakukan melalui media elektronik. Fenomena kini menunjukkan bahwa delik pencemaran nama baik yang memiliki spirit dan tujuan untuk melindungi reputasi seseorang, justru berpotensi digunakan untuk menyerang pihak tertentu.

Pada aspek penerapan hukumnya pun tidak luput dari berbagai permasalahan, dari aspek norma hukum baik pada Pasal 310 KUHP maupun Pasal 27 ayat (3) UU ITE dinilai masuk kategori pasal karet yang kerap memakan korban dan gencar disuarakan perubahannya. Selain itu, konsep pemidanaan Indonesia yang masih berorientasi pada pembalasan dengan mengutamakan sanksi pidana badan termasuk pada tindak pidana pencemaran nama baik ini semakin memperparah realita kondisi sosial di dalam lembaga pemasyarakatan.

"Het Recht Inackhter de Feiten Aan" adagium yang berarti "hukum selalu tertatih-tatih tertinggal di belakang kejadian atau peristiwa yang muncul di masyarakat nyatanya. 
Stigma negatif yang dihadapi para mantan narapidana setelah kembali ke masyarakat pun semakin mempersulit dan bertentangan dengan tujuan pemasyarakatan yaitu guna memberikan efek jera dan resosialisasi.

Sementara sistem hukum di berbagai negara seperti Inggris telah mendekriminalisasi pencemaran nama baik, sehingga menjadi suatu pelanggaran hukum perdata murni. Hal ini tentu bukan tanpa alasan, pencemaran nama baik pada praktiknya didominasi pada pelanggaran dan penyerangan antar individu (reputasi individu yang diserang). Dengan demikian, penyelesaian secara perdata menjadi lebih tepat diaplikasikan dan efektif memberikan keadilan bagi para pihak. Selain itu, penerapan hukum pidana pada delik tersebut juga berpotensi mengancam hak kebebasan berpendapat yang dijamin oleh konstitusi.

\section{Rumusan Masalah}

Berdasarkan latar belakang tersebut di atas maka permasalahan yang dirumuskan dalam artikel ini adalah: pertama, bagaimana problematika penegakan hukum atas delik pencemaran nama baik di Indonesia? Kedua, bagaimana urgensi dekriminalisasi pencemaran nama baik sehingga menjadi pelanggaran hukum perdata murni?

\section{Tujuan Penelitian}

Artikel ini bertujuan untuk mengkaji problematika penegakan hukum atas delik pencemaran nama baik di Indonesia dan argumentasi yang tepat mengenai urgensi dekriminalisasi delik pencemaran nama baik menjadi pelanggaran hukum perdata.

\section{Metode Penelitian}

Metode penelitian yang digunakan adalah yuridis normatif dengan pendekatan peraturan perundang-undangan dan analitis serta studi komparatif, sedangkan pengumpulan data melalui studi kepustakaan dengan pendekatan konseptual untuk menjelaskan dan mengaitkan dengan teori-teori yang relevan. Sumber data dalam penelitian ini menggunakan sumber data sekunder yang didapat dari literatur dan sumber hukum primer, sekunder, serta tersier. Hasil penelitian dianalisis dan diuraikan secara deskriptif kualitatif.

\section{Hasil Penelitian dan Pembahasan}

\section{Problematika Penegakan Hukum Delik Pencemaran Nama Baik di Indonesia}

Oemar Seno Adji menjabarkan definisi pencemaran nama baik sebagai menyerang kehormatan atau nama baik (aanranding of geode naam). Bentuk 
pencemaran nama baik dapat dilakukan secara tertulis maupun secara lisan dengan menuduhkan sesuatu hal. ${ }^{2}$ Namun, seiring dengan perkembangan teknologi dan informasi kini pencemaran nama baik dapat dilakukan melalui media elektronik baik berupa tulisan, gambar, gambar bergerak sepanjang dilakukan di ruang maya (cyberspace).

Pencemaran nama baik yang banyak dikenal dengan istilah penghinaan terbagi menjadi dua jenis yaitu penghinaan materil dan penghinaan formil. Penghinaan materil ${ }^{3}$ yaitu penghinaan yang didasarkan pada suatu kenyataan yang meliputi pernyataan yang objektif menggunakan kata-kata baik secara lisan maupun tertulis, sehingga isi pernyataan tersebut menjadi faktor yang paling menentukan. Namun, dalam hal tuduhan yang dilakukan oleh pelaku itu dilakukan oleh korban demi kepentingan umum, hal ini dapat dijadikan alasan pembenar bagi korban. Penghinaan formil ${ }^{4}$ menitikberatkan pada cara penghinaan itu dilakukan. Bentuk dan caranya menjadi faktor menentukan, bisa dilakukan dengan cara kasar maupun dengan cara yang tidak objektif. Jika ditafsirkan dengan tafsir sistematik, pengertian umum delik penghinaan adalah penyerangan terhadap kehormatan atau nama baik seseorang. ${ }^{5}$

Sistem hukum pidana di Indonesia telah lama mengatur mengenai pencemaran nama baik yang diatur dalam Pasal 310 sampai Pasal 321 KUHP. Meski begitu, KUHP tidak memberikan penjabaran mengenai definisi penghinaan. Namun, delik pencemaran nama baik ini dapat dilihat pada tiga pasal yang mendasarinya sebagai ketentuan umum delik pencemaran nama baik yaitu Pasal 310 ayat (1) KUHP, Pasal 310 ayat (2) KUHP dan Pasal 315 KUHP. Selain itu Undang-Undang Informasi dan Transaksi Elektronik juga mengakui perbuatan pencemaran nama baik secara elektronik yang dirumuskan dalam Pasal 27 ayat (3). Pasal tersebut menyatakan bahwa setiap orang dengan sengaja dan tanpa hak mendistribusikan dan/atau mentransmisikan dan/atau membuat dapat diaksesnya Informasi Elektronik dan/atau Dokumen Elektronik yang memiliki muatan penghinaan dan/atau pencemaran nama baik. Perbuatan tersebut diancam sanksi pidana dalam Pasal 45 ayat (1) yaitu pidana maksimal 6 (enam) tahun penjara dan/atau denda paling banyak Rp. 1.000.000.000,00.

Pemberlakuan Pasal 27 ayat (3) UU ITE juga tidak dapat dipisahkan dari norma hukum pokoknya yaitu dalam KUHP, khususnya Pasal 310 dan Pasal 311

2 Oemar Seno Adji, Perkembangan Delik Pers di Indonesia, Erlangga, Jakarta, 1990, hlm. 36.

3 Asrianto Zainal, "Pencemaran Nama Baik Melalui Teknologi Informasi Ditinjau Dari Hukum Pidana", Jurnal Al-'Adl, Vol. 9 No. 1, Januari 2016, hlm. 62.

${ }^{4}$ Ibid.

5 R Soesilo, Kitab Undang-Undang Hukum Pidana (KUHP) Serta Komentar-Komentarnya Lengkap Pasal Demi Pasal, Politeia, Bogor, 1996, hlm. 225. 
KUHP. Hal ini dikarenakan Pasal 27 ayat (3) UU ITE hanya merumuskan perluasan dan pencemaran nama baik melalui dunia maya. Perbedaan mendasar adalah media serta muatan yang disebarkan dalam UU ITE yang memuat pencemaran nama baik secara elektronik yang dimaksud dengan informasi elektronik yang memiliki muatan penghinaan dan/atau pencemaran nama baik dalam delik ini adalah satu atau sekumpulan data elektronik, termasuk tetapi tidak terbatas pada tulisan, suara, gambar, peta, rancangan, pencemaran nama baik, electronic data interchange (EDI), surat elektronik (e-mail), telegram, teleks, telecopy atau sejenisnya, huruf, tanda, angka, kode akses, simbol, atau perforasi yang telah diolah sehingga di dalamnya mengandung unsur penghinaan atau pencemaran nama baik seseorang.

Sistem hukum Indonesia tidak hanya memberikan ancaman atas perbuatan pencemaran nama baik atau penghinaan dari aspek hukum pidana saja, namun juga secara perdata. Penghinaan masuk dalam Buku Ketiga KUHPer tentang Perikatan. Penghinaan dalam KUHPer dikategorikan dalam genus perbuatan melawan hukum sebagaimana diatur dalam ketentuan Pasal 1365 KUHPer, sedangkan penghinaan secara khusus diatur dalam ketentuan Pasal 1372 sampai dengan 1380 KUHPer. Perbedaan mendasar antara larangan pencemaran nama baik dalam hukum pidana dan hukum perdata terletak pada cara dan tujuan penjatuhan sanksinya. Dalam hukum pidana berorientasi pada sanksi pidana badan dengan harapan dapat memberikan efek jera, sedangkan dalam hukum perdata memiliki tujuan agar dicapai ganti kerugian sebagai akibat yang ditimbulkan dari perbuatan mencemarkan nama baik tersebut. Selain itu, berguna juga untuk memulihkan kehormatan serta nama baik korban. Hal ini sebagaimana diatur dalam ketentuan Pasal 1372 KUHPer. Namun terdapat pengecualian, Hakim juga dapat untuk tidak mengabulkan tuntutan dari seseorang yang diduga nama baiknya telah dicemarkan apabila tidak ada maksud penghinaan di dalam perkara tersebut, yaitu yang bertujuan untuk kepentingan umum atau untuk membela diri.

Kasus pencemaran nama baik di Indonesia memiliki tren yang selalu meningkat setiap tahunnya terlebih pada kasus pencemaran nama baik melalui media elektronik. Hal ini dapat dilihat dalam tabel berikut: 
Tabel 1.1

Jumlah Aduan Kasus Pencemaran Nama Baik melalui UU ITE Periode 2018-2020

\begin{tabular}{cc}
\hline Tahun & Jumlah Aduan \\
\hline 2018 & 1.258 aduan \\
2019 & 1.333 aduan \\
2020 & 1.794 aduan \\
\hline
\end{tabular}

Sumber: Data Direktorat Tindak Pidana Siber (Dittipidsiber) Bareskrim Polri6

Seiring dengan perkembangan teknologi dan peningkatan jumlah pengguna internet di Indonesia menyebabkan banyak pula peningkatan kasus pencemaran nama baik melalui internet. Direktorat Tindak Pidana Siber (Dittipidsiber) Bareskrim Polri menangani 4.656 kasus tindak pidana siber sepanjang periode Januari hingga November 2020. Kasus terbanyak yang ditangani adalah perkara pencemaran nama baik sebanyak 1.743 kasus. ${ }^{7}$ Pada 2018 terdapat 1.258 laporan yang masuk ke instansi Polri, kemudian jumlah itu naik menjadi 1.333 pada 2019, dan kembali naik menjadi 1.794 laporan polisi pada 2020 terkait pencemaran nama baik. ${ }^{8}$ Banyaknya warga yang terjerat tuduhan penghinaan/pencemaran nama baik berhubungan erat dengan tingkat penggunaan internet di Indonesia. Dalam penerapannya kemudian ditemukan banyak masalah pada pasal-pasal delik pencemaran nama baik, baik yang diatur dalam Pasal 310 dan Pasal 311 KUHP maupun Pasal 27 ayat (3) UU ITE.

Pada aspek hukum materiil norma dalam pasal-pasal tersebut dinilai sebagai pasal karet yang mengandung unsur ketidakjelasan, menimbulkan multitafsir yang berimplikasi pada masalah dalam proses penerapannya di lapangan. Permasalahan tersebut tidak hanya ada di Pasal 27 ayat (3) UU ITE saja, namun Pasal 310 dan 311 KUHP pun mengandung ketidakjelasan tersendiri. Hal ini nampak pada belum adanya ukuran yang dapat menentukan suatu perbuatan dikategorikan sebagai pencemaran nama baik.

Pada hakikatnya, keberadaan Pasal tersebut bermaksud melindungi dan mempertegas kewajiban setiap orang untuk menghormati orang lain dari sudut kehormatannya dan nama baiknya di mata orang lain. Guna melihat korelasi antara kehormatan dan nama baik seseorang maka dalam hal ini harus diketahui definisinya masing-masing. Kehormatan adalah perasaan terhormat seseorang di mata masyarakat, di mana setiap orang memiliki hak untuk diperlakukan sebagai

\footnotetext{
6 https://www.pikiran-rakyat.com/nasional/pr-011571041/laporan-uu-ite-meningkat-tiap-tahun-polrikita-ingin-dunia-maya-di-indonesia-bisa-sehat?page $=2$, diakses pada 30 Maret 2021

7 https://www.cnnindonesia.com/nasional/20201229094838-12-587280/polri-tangani-4656-kasus-siberpencemaran-nama-baik-dominan, diakses pada 30 Maret 2021

8 https://www.pikiran-rakyat.com/nasional/pr-011571041/laporan-uu-ite-meningkat-tiap-tahun-polrikita-ingin-dunia-maya-di-indonesia-bisa-sehat?page $=2$, diakses pada 30 Maret 2021
} 
anggota masyarakat yang terhormat. Menyerang kehormatan berarti melakukan perbuatan menurut penilaian secara umum menyerang kehormatan seseorang. Rasa hormat dan perbuatan yang termasuk kategori menyerang kehormatan tersebut ditentukan menurut nilai-nilai yang ada di lingkungan masyarakat di mana perbuatan tersebut dilakukan. ${ }^{9}$ Berdasarkan penjabaran tersebut di atas, maka seharusnya norma delik pencemaran nama baik dalam KUHP turut serta diperjelas indikatornya.

Selain pada aspek materiil, delik ini juga menimbulkan berbagai permasalahan pada aspek formil (penegakanya). Pada delik pencemaran nama baik sesuai ketentuan Pasal 27 ayat (3) UU ITE merupakan salah satu ketentuan yang paling banyak dikritisi. Hal ini dikarenakan pasal tersebut merupakan duplikasi tindak pidana pencemaran nama baik dalam KUHP yang perumusannya tidak kalah luas serta multitafsir. Hal ini menimbulkan masalah dalam penerapannya yang justru tidak memberikan kepastian hukum karena tidak ada standar penerapannya. Pasal tersebut diterapkan secara beragam, mulai dari proses penyidikan, dakwaan, prosedur penahanan, prosedur pencabutan laporan dan mediasi, termasuk dalam menafsirkan pasal itu sendiri. ${ }^{10}$

Selain itu, Pasal 27 ayat (3) UU ITE tidak memiliki penjelasan yang jelas pada masing-masing unsur tindak pidananya, khususnya pada unsur perbuatan yang bersifat teknis seperti "mendistribusikan" dan "mentransmisi". Hal ini berdampak pada penafsiran aparatur penegak hukum yang berbeda-beda. Unsur "tanpa hak" juga tidak memiliki penjelasan dalam UU ini. Keberadaan unsur pasal ini justru menimbulkan pertanyaan apakah ada kondisi tertentu yang menyebabkan seseorang memiliki kewenangan untuk melakukan pencemaran nama baik atau penghinaan.

Dalam perjalanannya UU ITE mengalami perubahan pada tahun 2016, sejumlah unsur delik tersebut diberikan penjelasan termasuk Pasal 27 ayat (3) namun perubahan tersebut hanya memberikan penegasan bahwa ketentuan pada ayat tersebut mengacu pada ketentuan pencemaran nama baik dan/atau fitnah yang diatur dalam KUHP. Walaupun begitu, disepakati bahwa penerapannya merujuk terbatas pada ketentuan pencemaran nama baik dan/atau fitnah yang diatur di dalam Pasal 310 dan Pasal 311, padahal pasal dalam KUHP itu sendiri mengandung ketidakjelasan indikator perbuatan. Selain itu, perubahan terdapat pada ketentuan ancaman pidana yang sebelumnya banyak dikritik karena terlalu tinggi sehingga dalam penerapannya banyak dilakukan penahanan. Perubahan

${ }_{9}$ Mudzakir, Delik Penghinaan dalam Pemberitaan Pers Mengenai Pejabat Publik, Atmajaya Pres, Yogyakarta, 2004, hlm. 17.

10 https://icjr.or.id/wp-content/uploads/2021/03/ICJR_Mengatur-Ulang-Kebijakan-Pidana-di-RuangSiber.pdf, diakses 5 April 2021 
tersebut dengan menurunkan ancaman penjara dari maksimum enam tahun penjara dan/atau denda paling banyak Rp. 1.000.000.000,00, menjadi maksimum empat tahun penjara dan/atau denda paling banyak Rp. 750.000.000,00. Meski begitu, penurunan ancaman pidana di bawah lima tahun penjara hanya berimplikasi pada sulit ditahannya tersangka dalam proses pemeriksaan. ${ }^{11}$

Kompleksitas permasalahan norma dan penerapan Pasal 27 ayat (3) UU ITE membuat banyak kalangan mengusulkan agar pasal tersebut dihapuskan karena berpotensi dimanfaatkan oleh pihak-pihak tertentu dan dari aspek kebijakan hukum menimbulkan adanya duplikasi pengaturan mengingat dalam revisinya pasal tersebut juga ditegaskan merujuk pada ketentuan Pasal 310 dan 311 KUHP.

Pada Februari 2021 lalu, Presiden Jokowi membuat pernyataan terkait maraknya fenomena saling adu lapor kasus pencemaran nama baik di Indonesia. Dalam pidatonya Presiden menyatakan bahwa UU ITE khususnya yang berkaitan dengan pencemaran nama baik harus dievaluasi. Kapolri menindaklanjutinya dengan mengeluarkan Surat Telegram dengan Nomor ST/339/II/RES.1.1.1./2021 tentang Pedoman Penanganan Hukum Kejahatan Siber berupa pencemaran nama baik, fitnah ataupun penghinaan (selanjutnya disebut "ST") terkait dengan pencemaran nama baik dapat diselesaikan dengan upaya restorative justice. Kasus itu tidak hanya mencakup pencemaran nama baik di UU ITE namun juga KUHP yaitu Pasal 27 ayat (3) UU ITE; Pasal 207 KUHP; Pasal 310 KUHP; Pasal 311 KUHP. Selain opsi penyelesaian secara restorative justice, ST tersebut juga menyatakan untuk tidak dilakukan penahanan terhadap tindak pidana pencemaran nama baik/fitnah/penghinaan.

Di beberapa negara perbuatan pencemaran nama baik diatur dalam peraturan perundang-undangan sendiri. Contohnya di Negara Australia dan Inggris. Australia mengklasifikasikan pencemaran nama baik menjadi dua jenis yaitu dari aspek hukum pidana dan perdata. Pencemaran nama baik dalam ranah hukum pidana yaitu perbuatan pencemaran nama baik yang menimbulkan akibat terganggunya kepentingan umum dan/atau menimbulkan kekacauan di masyarakat yang tidak hanya mengganggu reputasi orang lain, namun juga berdampak terhadap komunitas yang lebih luas dan berpotensi merusak perdamaian di lingkungan masyarakat. ${ }^{12}$ Hal ini diatur dalam Section 365 Defamation Act of Australia 2005 dengan ancaman pidana maksimum tiga tahun penjara. Sedangkan pencemaran nama baik yang masuk ranah hukum perdata adalah perbutaan pencemaran nama baik yang hanya merugikan kepentingan individu semata, ${ }^{13}$ Pihak yang melakukan

\footnotetext{
${ }^{11}$ Lihat ketentuan Pasal 21 ayat (4a) KUHAP.

12 www.efa.org.au/Issues/Cencor/defamation, diakses pada 5 April 2021

13 Article 12 Defamation Act of Australia 2005
} 
pencemaran nama baik dapat menawarkan ganti kerugian kepada pihak yang dirugikan, berupa pembayaran sejumlah uang dan/atau permintaan maaf dengan cara-cara sebagaimana yang diatur dalam Article 15, Defamation Act 2005.

Inggris juga mengatur secara khusus larangan perbuatan pencemaran nama baik dalam Defamation Act 2013 Jo. Defamation Act 1996. Menurut hukum Inggris, seseorang akan dianggap melakukan pencemaran nama baik ketika menuduh atau memberikan pernyataan di muka umum, baik secara langsung maupun melalui tulisan mengenai seseorang atau beberapa orang yang menyebabkan reputasi orang tersebut menjadi rusak di mata publik, apalagi sampai mengakibatkan orang tersebut kehilangan pekerjaan. ${ }^{14}$ Penyelesaiannya dilakukan dengan cara memberikan kesempatan untuk mengajukan permintaan maaf kepada korban dengan membuat pernyataan resmi tertulis yang dipublikasikan serta memberikan kompensasi dengan besaran jumlah yang telah disepakati bersama. ${ }^{15}$ Dalam hal kedua upaya tersebut tercapai, maka korban tertutup jalan melanjutkan kembali kasus ke pengadilan. Guna mencapai pemenuhan kesepakatan tersebut, pihak yang dirugikan dapat mengajukan permohonan pada pengadilan untuk membantu. Apabila dalam perjalanannya tidak tercapai kesepakatan mengenai jumlah kompensasi yang harus dibayarkan, maka selanjutnya akan ditentukan oleh pengadilan.

Penegakan hukum atas pencemaran nama baik di Australia memang diberikan dua aspek jalur. Namun penegakan hukum secara perdata diutamakan penyelesaiannya, sehingga sejalan dengan ajaran hukum pidana, yaitu hukum pidana sebagai ultimum remedium. Penyelesaian secara perdata sebagaimana diterapkan di Inggris juga menjadi alternatif penyelesaian yang solutif dan tidak menimbulkan suatu masalah baru serta dinilai dapat memenuhi rasa keadilan bagi kedua belah pihak. Hal ini terlihat berbeda dengan pengaturan delik pencemaran nama baik di Indonesia, dimana seseorang dapat dituntut secara perdata dan pidana atas kasus yang sama. Namun dalam praktiknya, putusan hakim atas kedua tuntutan tersebut kadangkala berbeda dan bertentangan. Hal ini kejadian yang pernah terjadi dalam kasus Prita Mulyasari dan menimbulkan ketidakpastian hukum.

\section{Urgensi Dekriminalisasi Delik Pencemaran Nama Baik dan Menjadikannya Murni sebagai Pelanggaran Hukum Perdata}

Dekriminalisasi delik pencemaran nama baik dinilai menjadi terobosan dan solusi guna menanggulangi berbagai permasalahan yang selama ini timbul dari

\footnotetext{
14 Article 2 point (2) dan point (3) Defamation Act of United Kingdom 1996

15 Article 2 point (5) Defamation Act of United Kingdom 1996
} 
proses penegakan hukum atas Pasal 310 KUHP dan Pasal 27 ayat (3) UU ITE. Dekriminalisasi merupakan sebuah pengakuan negara bahwa tindakan yang dulu dianggap sebagai delik menjadi tindakan yang bukan lagi dianggap delik.16 Dekriminalisasi terjadi atas dasar pertimbangan filosofis, sosiologis dan yuridis, sehingga suatu peraturan dapat berubah dengan adanya perubahan paradigma terhadap suatu delik.

Roeslan Saleh menyebutkan pidana yang berlebihan dipandang tidak akan mampu mencapai tujuan-tujuan pemidanaan, justru yang terjadi akan bertentangan dengan tujuan pemidanaan tersebut. Hal ini dikarenakan:17

a. Pidana yang terlalu berat bahkan akan mendorong terjadinya lebih banyak kejahatan. Jika karena kejahatan-kejahatan ringan orang dipidana sama dengan mereka yang melakukan kejahatan berat, maka orang bisa jadi justru akan termotivasi melakukan kejahatan berat;

b. Pidana yang dijatuhkan terlalu berat akan menghalangi orang melaporkan tentang adanya suatu kejahatan sehingga membuat banyak kejahatan tidak dipidana;

c. Pidana yang dijatuhkan terlalu berat mengakibatkan UU tidak digunakan oleh hakim dan justru akan dikesampingkan sehingga menggoyahkan nilai-nilai kepastian hukum.

Pidana penjara dinilai memiliki beberapa kelemahan khususnya pada pidana penjara yang dijatuhkan dalam waktu yang singkat antara satu bulan hingga satu tahun. Pidana penjara dalam waktu yang singkat relatif singkat tidak dapat memperbaiki pelaku tindak pidana. Selain itu, justru membebani negara akibat pembiayaan di dalam penjara yang ditanggung oleh negara. ${ }^{18}$ Sejalan dengan pola penjatuhan sanksi terhadap delik pencemaran nama baik di Indonesia yang rata-rata divonis antara tiga bulan hingga satu atau dua tahun. Sementara setelah selesai menjalani masa pidananya ia menghadapi berbagai masalah sosial baru di masyarakat, stigma negatif yang tidak hanya untuk ditujukan pada pribadinya namun juga keluarga serta kerabatnya, sulitnya mencari pekerjaan yang mengakibatkan kesulitan memenuhi kebutuhan hidupnya, sehingga justru berpotensi membuat ia melakukan tindakan kriminal karena faktor ekonomi. Hal ini jelas sangat bertentangan dengan tujuan pemidanaan yaitu perlindungan masyarakat dan pembinaan pelakunya.

16 Andi Intan Purnamasari, "Dekriminalisasi Tindak Pidana : Membedah Keadilan Bagi Terpidana dan Mantan Terpidana”, Gorontalo Law Review, E-ISSN: 2614-5030, P-ISSN: 2614-5022 Volume 2 No. 1, - April 2019, hlm. 15.

${ }_{17}$ Roeslan Saleh, Beberapa Asas Hukum Pidana Dalam Perspektif, Aksara Baru, Jakarta, 1983, hlm. 39.

18 Lilik Mulyadi, Menggagas Model Ideal Pedoman Pemidanaan Dalam Sistem Hukum Pidana Indonesia, Kencana, Jakarta, 2020, hlm. 8 . 
Selain menimbulkan permasalahan baru, penjatuhan sanksi pidana badan juga semakin memperparah kondisi over capacity lembaga pemasyarakatan di seluruh Indonesia yang selain memperberat anggaran negara juga justru berpotensi melanggar hak-hak asasi warga binaan di dalamnya. Oleh karena itu, sanksi pidana dinilai tidak efektif mengingat seringkali output penegakan hukumnya tidak dapat memenuhi rasa keadilan bagi pihak lain yang merasa dirugikan, terlebih jika menyangkut kerugian materiil. Selain itu, kecenderungan yang terjadi adalah pihak yang berkonflik adalah sesama individu sehingga lebih tepat dijatuhkan sanksi dengan mengikuti pola penjatuhan sanksi hukum perdata sebagaimana diterapkan di Inggris dengan kualifikasi Perbuatan Melawan Hukum (PMH) secara hukum perdata.

PMH adalah suatu bentuk perikatan yang lahir dari UU sebagai akibat dari perbuatan manusia yang melanggar hukum. Hal ini diatur dalam Pasal 1365-1380 KUHPer Buku III. ${ }^{19}$ Berdasarkan ketentuan Pasal 1365 KUHPer, yang dimaksud dengan $\mathrm{PMH}$ adalah "Perbuatan yang melawan hukum yang dilakukan oleh seseorang yang karena kesalahannya telah menimbulkan kerugian bagi orang lain. Sedangkan dalam arti sempit, PMH berarti "Orang yang berbuat pelanggaran terhadap hak orang lain atau telah berbuat bertentangan dengan suatu kewajiban hukum". ${ }^{20}$ Perbuatan pelanggaran terhadap hak orang lain, hakhak yang dilanggar tersebut adalah hak-hak yang diakui oleh hukum, termasuk namun tidak terbatas pada hak-hak sebagai berikut yaitu hak-hak pribadi hakhak kekayaan, hak atas kebebasan, dan hak atas kehormatan dan nama baik. Meskipun dulunya secara sempit PMH ditafsirkan hanya terhadap hukum tertulis saja, namun sejak 1919 Mahkamah Agung Belanda dalam kasus Arrest Cohen-Lindenbaum (H.R. 31 Januari 1919) dalam putusannya memperluas definisi melawan hukum yang tadinya hanya sebatas hukum tertulis maka diperluas juga dengan turut mencakup hukum tidak tertulis, antara lain: ${ }^{21}$

a. Melanggar UU/hukum tertulis;

b. Melanggar hak subjektif orang lain yaitu hak-hak seseorang yang dijamin oleh negara termasuk namun tidak terbatas pada hak yang bersifat pribadi, kebebasan, hak kebendaan, kehormatan, nama baik ataupun hak perorangan lainnya;

c. Bertentangan dengan kewajiban hukum pelaku (baik kewajiban hukum tertulis maupun tidak tertulis;

d. Bertentangan dengan norma kesusilaan ysng berlaku sebagai the living law dan/atau hukum positif;

${ }^{19}$ Gunawan Widjaja dan Kartini Muljadi, Seri Hukum Perikatan-Perikatan Yang Lahir Dari Undang-Undang, PT.Raja Grafindo Persada, Jakarta, 2017, hlm. 81.

${ }^{20}$ H.F.A.Volmar, Pengantar Studi Hukum Perdata, Rajawali Pers, Jakarta, 1984, hlm. 50.

${ }^{21}$ Putusan Mahkamah Agung Belanda dalam kasus Arrest Cohen-Lindenbaum (H.R. 31 Januari 1919). 
e. Bertentangan dengan prinsip kehati-hatian dalam kehidupan bermasyarakat. Indikatornya bersumber pada hukum tak tertulis, yaitu nilai-nilai kepatutan dalam masyarakat.

Berdasarkan penjabaran tersebut di atas, maka nampak jelas pada hakikatnya pencemaran nama baik sangat tepat jika murni dijadikan pelanggaran hukum perdata. Hal ini dikarenakan dalam pencemaran nama baik perbuatan pelaku adalah tindakan yang melanggar hak yang diakui oleh hukum yaitu hak atas kehormatan dan nama baik. Akan menjadi semakin nyata ketika tidak hanya nama baik yang dirugikan, namun sampai pada menimbulkan kerugian secara materiil sehingga turut serta melanggar hak kekayaan. Tidak hanya kerugian materiil yang dapat diajukan tuntutan ganti kerugian, namun juga kerugian yang bersifat immateriil. Kerugian immateriil mencakup timbulnya ketakutan, kekecewaan, rasa penyesalan, menyebabkan sakit yang pada prakteknya akan dinilai dalam bentuk materi atau uang. Sepanjang kedua jenis kerugian tersebut dapat dibuktikan ada hubungan kausalitas langsung antara perbuatan dan kerugian yang diakibatkan.

Ketentuan hukum perdata yang ada dinilai mampu mengakomodasi kebutuhan hukum yang ada tanpa perlu mendesain ulang regulasi yang ada yaitu Pasal 1372-1380 KUHPer yang masuk dalam genus PMH. Penghapusan/ dekriminalisasi sanksi pidana dalam kasus pencemaran nama baik dalam KUHP dan/atau UU ITE dinilai lebih tepat, hal ini sebagaimana yang diterapkan oleh Inggris dalam menangani perkara pencemaran nama baik.

Melakukan dekriminalisasi atas delik pencemaran nama baik turut serta menjadi solusi atas permasalahan over capacity lapas yang kian memprihatinkan. Sementara Herman Mannheim menyebutkkan bahwa hukum pidana adalah salah satu cermin yang paling terpercaya mengenai peradaban suatu bangsa. Hal ini berarti hukum pidana merupakan refleksi nilai-nilai dasar suatu masyarakat. ${ }^{22}$ Cerminan HAM, keadilan, dan implementasi formulasi norma hukum. Selain itu juga dalam rangka mengembalikan eksistensi ultimum remedium yang pada hakikatnya hukum pidana merupakan upaya terakhir setelah upaya hukum lain dianggap tidak mampu menanggulangi masalah yang ada.

\section{Penutup}

Penegakan hukum atas delik pencemaran nama baik di Indonesia selama ini lebih dominan dilakukan melalui jalur hukum pidana, meskipun hukum positif juga telah mengakomodasi penyelesaian melalui hukum perdata. Pada aspek

${ }^{22}$ Lilik Mulyadi, Op. Cit., hlm. 2 
hukum pidana materiil, norma dalam Pasal 310 KUHP dan Pasal 27 ayat (3) UU ITE dinilai sebagai pasal karet yang mengandung unsur ketidakjelasan sehingga menimbulkan multitafsir. Hal ini berakibat pada penerapan hukum secara beragam, mulai dari proses penyidikan, dakwaan, prosedur penahanan, prosedur pencabutan laporan dan mediasi, termasuk dalam menafsirkan pasal itu sendiri. Sistem penjatuhan sanksi hukum pidana di Indonesia yang masih berorientasi pada pidana badan termasuk pada delik pencemaran nama baik ini turut serta memberikan kontribusi pada berbagai permasalahan yang ada seperti over capacity Lapas yang sangat berpotensi melanggar hak-hak asasi narapidana.

Selain itu, sanksi pidana badan dinilai tidak efektif guna menyelesaikan perkara pencemaran nama baik yang sesungguhnya mayoritas menyerang hakhak individu, hak kehormatan, dan hak atas nama baik sehingga akan lebih memenuhi rasa keadilan jika diselesaikan melalui penyelesaian hukum perdata. Selain itu, sanksi pidana badan dinilai memperberat anggaran negara dan justru berpotensi melanggar hak-hak asasi warga binaan di dalamnya mengingat kondisi Lapas yang kelebihan kapasitas. Sanksi pidana badan juga tidak efektif menimbulkan efek jera bagi pelaku, justru menimbulkan banyak kerugian dan kesulitan bagi pelaku setelah selesai menjalani hukuman. Pelaku akan mendapatkan stigma negatif di masyarakat yang semakin mempersulit posisinya di masyarakat. Oleh karena itu, sanksi pidana dinilai tidak efektif dan tidak sepenuhnya dapat memenuhi rasa keadilan baik bagi pelaku maupun korban terlebih jika sampai pada timbulnya kerugian materiil. Selain itu, mayoritas kasus terjadi antar individu sehingga lebih tepat diselesaikan dengan penyelesaian secara perdata dengan kualifikasi PM. Hal ini mengingat bahwa dekriminalisasi delik pencemaran nama baik dinilai menjadi solusi dan mengembalikan eksistensi hukum pidana sebagai ultimum remedium.

\section{Daftar Pustaka}

\section{Buku}

Mudzakir, Delik Penghinaan dalam Pemberitaan Pers Mengenai Pejabat Publik, Atmajaya Pres, Yogyakarta, 2004.

Mulyadi, Lilik, Menggagas Model Ideal Pedoman Pemidanaan Dalam Sistem Hukum Pidana Indonesia, Cetakan Pertama, Kencana, Jakarta, 2020.

Prasetyo, Teguh, Hukum Pidana I, Cetakan Pertama, Jakarta, PT. Raja Grafinfo Persada, 2010.

Saleh, Roeslan, Beberapa Asas Hukum Pidana Dalam Perspektif, Cetakan Pertama, Aksara Baru, Jakarta, 1983.

Seno Adji, Oemar, Perkembangan Delik Pers di Indonesia, Erlangga, Jakarta, 1990. 
Soesilo, R, Kitab Undang-Undang Hukum Pidana (KUHP) serta KomentarKomentarnya Lengkap Pasal Demi Pasal, Cetakan Pertama, Politeia, Bogor, 1996.

Volmar, H.F.A., Pengantar Studi Hukum Perdata, Rajawali Pers, Jakarta, 1984.

Widjaja, Gunawan, Seri Hukum Perikatan-Perikatan Yang Lahir Dari UndangUndang, Cetakan Pertama, PT.Raja Grafindo Persada, Jakarta, 2017.

\section{Jurnal}

Asrianto Zainal, "Pencemaran Nama Baik Melalui Teknologi Informasi Ditinjau Dari Hukum Pidana", Jurnal Al-'Adl, Vol. 9 No. 1, Januari 2016.

Andi Intan Purnamasari, "Dekriminalisasi Tindak Pidana : Membedah Keadilan Bagi Terpidana Dan Mantan Terpidana", Jurnal Gorontalo Law Review, Vol. 2, No. 1 - April 2019.

\section{Internet}

"Laporan UU ITE Meningkat Tiap Tahun, Polri: Kita Ingin Dunia Maya di Indonesia Bisa Sehat," https://www.pikiran-rakyat.com/nasional/pr011571041/laporan-uu-ite-meningkat-tiap-tahun-polri-kita-ingin-duniamaya-di-indonesia-bisa-sehat?page=2, diakses pada 30 Maret 2021.

"Polri Tangani 4.656 Kasus Siber, Pencemaran Nama Baik Dominan", https://www.cnnindonesia.com/nasional/20201229094838-12-587280/polritangani-4656-kasus-siber-pencemaran-nama-baik-dominan, diakses pada 30 Maret 2021.

"Mengatur Ulang Kebijakan Pidana di Ruang Siber," https://icjr.or.id/wpcontent/uploads/2021/03/ICJR_Mengatur-Ulang-Kebijakan-Pidana-di-RuangSiber.pdf, diakses 5 April 2021.

"Defamation Laws and the Internet", www.efa.org.au/Issues/Cencor/defamation , diakses pada 5 April 2021.

\section{Peraturan Perundang-Undangan}

Kitab Undang-Undang Hukum Pidana

Kitab Undang-Undang Hukum Acara Pidana

Kitab Undang-Undang Hukum Perdata

Undang-Undang No. 11 Tahun 2008 tentang Informasi dan Transaksi Elektronik Jo. Undang-Undang No. 19 Tahun 2016 tentang Perubahan atas UndangUndang No. 11 Tahun 2008 tentang Informasi dan Transaksi Elektronik (UU ITE)

Defamation Act of Australia 2005

Defamation Act of United Kingdom 1996

Putusan Pengadilan

Putusan Mahkamah Agung Belanda dalam kasus Arrest Cohen-Lindenbaum (H.R. 31 Januari 1919). 